\title{
Haemoglobinopathies in pregnancy
}

\author{
R. G. HUNTSMAN \\ From the Memorial University of Newfoundland, St John's, Newfoundland, Canada
}

The haemoglobinopathies are a heterogenous group of disorders which have highly variable clinical manifestations. At one end of the spectrum there is incompatibility with life and, at the other end, the patient under a stress, such as pregnancy, may experience some deterioration in her normal healthy state. Outside this wide range lie the symptomless carrier states which may demand obstetric action only because of problems connected with genetic counselling or antenatal diagnosis.

It must be instantly apparent that the possible pathology to be expected during the pregnant state will vary from one clearly defined genetic entity to another. On top of this, even within one clearly defined disease process, eg, sickle-cell anaemia, there are widely varying degrees of clinical severity. Some women with sickle-cell anaemia appear to have child after child effortlessly, whilst others are racked with crisis after crisis during their first pregnancy until, at some point (often around the time of delivery), they eventually succumb. Some of the extenuating factors are becoming understood but in many cases the different clinical course run by the same genetic disease is quite inexplicable.

An understanding of the underlying pathologywhich leads on to an attempt to rationalize obstetric management-depends upon a basic knowledge of protein structure and simple Mendelian genetics. Once these are understood, the classification of the haemoglobinopathies is easily comprehended.

In the haemoglobinopathies, the anaemia is due to lack of the normal protein globin, which is an essential part of the haemoglobin molecule, and the red cells produced have a shortened life span, causing a chronic haemolytic anaemia.

This lack of normal globin may be due to either: (1) the manufacture within the developing red cell of an abnormal globin which, when combined with haem, results in an abnormal haemoglobin; (2) failure of the developing red cell to produce enough globin (thalassaemia). In this case, the affected gene produces either an inadequate amount of globin or no globin at all.

Both the abnormal haemoglobins and the thalassaemias give rise to health problems of immense proportions. The World Health Organization estimate that each year 80000 children die (mainly in central Africa) of sickle-cell anaemia and 100000 children die of $\beta$ thalassaemia major. Whilst $\beta$ thalassaemia major remains a lethal childhood disease, better medical care now permits many patients with sickle-cell anaemia to live long enough to become pregnant and conceive children. Because of large-scale immigration, many doctors in the United Kingdom now have first-hand experience of both these disorders and it is with sickle-cell haemoglobin and $\beta$ thalassaemia that this article is mainly concerned.

\section{The Structure of Haemoglobin}

The haemoglobins are a group of related proteins (globins) to each of which the same prosthetic group haem (an iron-porphyrin complex) is attached. The function of the globin is to make the haem soluble and at the same time to prevent its ferrous iron atom from becoming permanently oxidized to the ferric form, which cannot combine with a molecule of oxygen.

There are 20 structurally different types of aminoacids. Globin contains a total of about 150 of them, the 20 different varieties being linked together by peptide bonds to form a polypeptide chain. The exact aminoacid occupying each of the sites of a polypeptide chain is predetermined by the DNA of the structural gene responsible for its manufacture.

There are three important normally occurring human haemoglobins. These haemoglobins differ from each other because they are constructed from different polypeptide chains, which have been given the letters of the Greek alphabet $\alpha$ (alpha), $\beta$ (beta), $\gamma$ (gamma) and $\delta$ (delta). For example, all normal human $\alpha$ chains are similar to each other but they differ from the $\beta, \gamma$ and $\delta$ chains because the aminoacids are arranged in a different order. Similarly the normal human $\beta, \gamma$ and $\delta$ chains all have their own specific aminoacid sequence determined by their own structural genes. Other haemoglobins have been described containing $\epsilon$ (epsilon) and $\zeta$ (zeta) chains but they are not of practical importance. 
1 adult haEMOglobin (HAEMoglobin A) This is the normal haemoglobin of the adult comprising about 98 per cent of the total. Two pairs of polypeptide chains make up each completed molecule. One pair is made of two $\alpha$ polypeptide chains and the other pair of two $\beta$ chains.

Adult haemoglobin $=\alpha_{2} \beta_{2}$

\begin{tabular}{|l|l|}
\hline$\alpha$ & $\beta$ \\
\hline$\beta$ & $\alpha$ \\
\hline
\end{tabular}

\section{FETAL HAEMOGLOBIN}

A baby is born with about 70 per cent of fetal haemoglobin and 30 per cent of adult haemoglobin. The fetal haemoglobin is virtually all replaced by adult haemoglobin in the first year of life, dropping to a level of under 2 per cent of the total haemoglobin present in the adult. Fetal haemoglobin has a pair of $\gamma$ chains instead of the $\beta$ chains of adult haemoglobin.

Fetal haemoglobin $=\alpha_{2} \gamma_{2}$

\begin{tabular}{|l|l|}
\hline$\alpha$ & $\gamma$ \\
\hline$\gamma$ & $\alpha$ \\
\hline
\end{tabular}

It is usual to find a raised level of fetal haemoglobin in adults with sickle-cell disease and haemoglobins $\mathrm{C}, \mathrm{D}$ and $\mathrm{E}$ disease. The carriers of haemoglobin S, C, D or E do not have raised levels of fetal haemoglobin.

Patients with $\beta$ thalassaemia major have a raised percentage of fetal haemoglobin. Fetal haemoglobin is elevated in about half the carriers of $\beta$ thalassaemia ( $\beta$ thalassaemia minor).

Some individuals fail to switch off their fetal haemoglobin production during their first few months of life. This condition (hereditary persistence of fetal haemoglobin) is unassociated with disease and is of theoretical rather than practical importance. It must, however, be admitted that pregnancy in a woman with 100 per cent of fetal haemoglobin in her red cells would provide a fascinating study of oxygen transport across the placenta. Such a situation has yet to be described in a woman in the pregnant state.

In late pregnancy small quantities of fetal haemoglobin may be produced by normal mothers (Pembrey and Weatherall, 1971), suggesting a hormonal reactivation of the now dormant $\gamma$ polypeptide chain gene, a reactivation which sometimes occurs in some unrelated haematological disorders such as leukaemia.

3 HAEMOGLOBIN $\mathrm{A}_{2}$ This is present in the normal adult at a level of about 2 per cent. Haemoglobin $\mathrm{A}_{2}$ has a pair of $\delta$ chains linking with a pair of $\alpha$ chains.
Haemoglobin $\mathrm{A}_{2}=\alpha_{2} \delta_{2}$

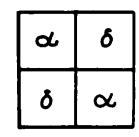

Raised levels of haemoglobin $A_{2}$ are found in the great majority of the carriers of $\beta$ thalassaemia.

\section{Inheritance}

THE INHERITANCE OF SICKLE-CELL ANAEMIA AND $\beta$ THALASSAEMIA

The common and clinically important haemoglobinopathies are due to production of abnormal $\beta$ chains ( $\beta$ chain abnormal haemoglobins) or inadequate production of $\beta$ chains ( $\beta$ thalassaemia). Both $\alpha$ polypeptide chain abnormal haemoglobins and $\alpha$ thalassaemia are relatively uncommon, the latter being considered briefly at the end of this section.

Some polypeptide chain genes, eg, the $\gamma$ and probably the $\alpha$ polypeptide chain genes of human haemoglobin, have duplicated, producing two loci responsible for their polypeptide chain production but the father and mother still contribute an equal number of genes.

If a gene undergoes a mutation, that abnormal gene still carries the information to produce an end product almost identical to the original normal polypeptide chain. However, at a single position, because of the mutation, a different aminoacid will be substituted for the one that normally occurs at that position in the normal polypeptide chain. A severely malfunctioning abnormal haemoglobin molecule may result from the combination of haem with a globin which possesses only this minute abnormality.

Other types of abnormal haemoglobins with aminoacid deletions or additions also exist. Again, abnormal polypeptide chains may be produced which contain conjoined parts of two different polypeptide chains, eg, $\delta-\beta$ chains. All these variations of abnormal haemoglobin are uncommon and only those abnormal haemoglobins (such as sickle-cell haemoglobin) containing the single aminoacid substitution need concern us.

Commonly both genes for the $\beta$ polypeptide chain are normal and such a person is, at this gene locus, a normal homozygote. The normal gene may be called 'A' (for adult haemoglobin). A normal person may be represented by the figure

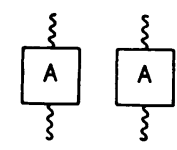

which shows a section of the chromosomes carry 
ing the structural genes responsible for $\beta$ polypeptide chain production. Gene

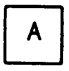

produces a normal $\beta$ polypeptide chain as is found in normal adult haemoglobin. A person with two A genes (genotype AA) will thus produce normal adult haemoglobin only.

Using such a diagrammatic approach a sicklecell carrier and a patient with sickle-cell anaemia could be illustrated as below:

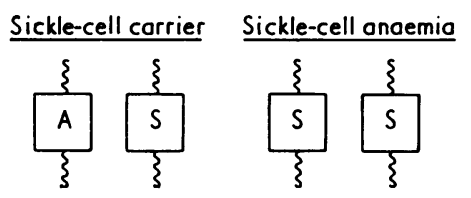

Gene $\mathrm{S}$ produces the abnormal $\beta$ polypeptide chain characteristic of sickle-cell haemoglobin (where the aminoacid valine has been substituted for glutamic acid in the sixth position of the $\beta$ polypeptide chain). $\beta$ thalassaemia may be illustrated in a similar way.

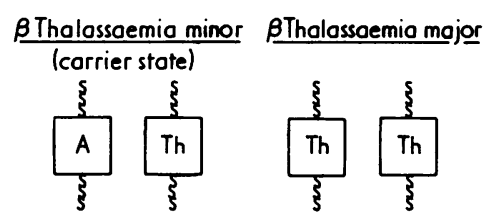

\section{Genetic Counselling and Antenatal Diagnosis}

Both sickle-cell anaemia and $\beta$ thalassaemia major can be avoided if carriers do not marry carriers.

SICKLE-CELL ANAEMIA

Sickle-cell anaemia commonly results from the mating of a sickle-cell carrier to a sickle-cell carrier (figure 1).
If a sickle-cell trait carrier mates with a sickle-cell trait carrier on average one quarter of their children will be normal, one half will be sickle-cell trait carriers, and one quarter will have sickle-cell anaemia.

With a carrier rate of 10 per cent (a reasonably accurate figure for the negro population of Great Britain), there is a one in a hundred chance of a carrier marrying a carrier. It follows that there is a one in four hundred chance that a baby born to black parents in the United Kingdom will have sickle-cell anaemia. These figures demonstrate that the virtually symptomless carrier state is common and the potentially lethal disease state, sickle-cell anaemia, is by comparison very much rarer.

Sickle-cell carriers have red cells which contain about 25 per cent to 40 per cent of sickle-cell haemoglobin and patients with sickle-cell anaemia have red cells containing about 90 per cent of sicklecell haemoglobin, the remaining 10 per cent being mostly fetal haemoglobin. Tests which merely detect sickle-cell haemoglobin, eg, the 'sickling' test, which uses intact red cells, and the widely used solubility tests, will give a positive result for both the carrier and sickle-cell anaemia. Differentiation between these two conditions (which are clinically as different as chalk and cheese) is best achieved in the laboratory by electrophoresis, which separates normal adult and sickle-cell haemoglobin by their different mobilities in an electric field. Ultimately a family study may be invaluable to differentiate some of the more unusual haemoglobinopathies.

Programmes designed to limit sickle-cell anaemia by genetic counselling have been launched, especially amongst the black population of the United States. Their experience suggests that a hastily organized programme may well be supported by inadequate diagnostic standards (Whitten, 1973). If such a programme is to be initiated in the United Kingdom the impetus should come from the immigrant population itself-a not unreasonable requirement considering the number of West Indian nurses in the National Health Service. Such a programme would best be aimed at the level of the school leaver-old enough to

Sickle cell carrier

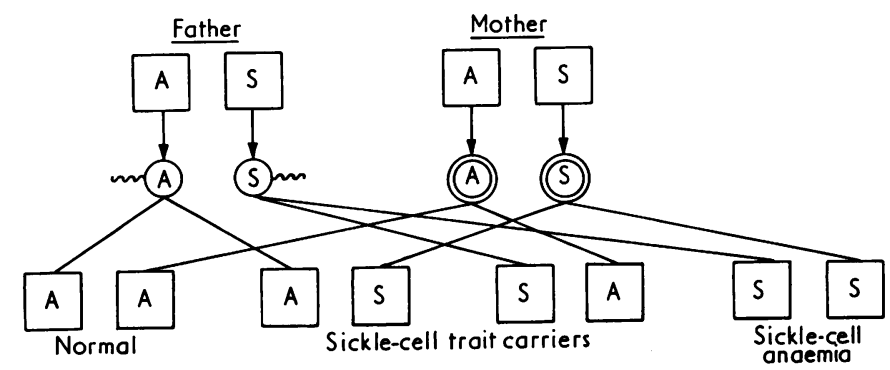

Children

Fig 1

Reduction division

Random fertilization

Fig 1 
understand the information given but without marital attachments.

Screening of antenatal patients for 'sickling' (a term best avoided as it obscures the fundamental difference between the carrier and the disease state) is liable to produce large numbers of sickle-cell carriers in a condition too late to benefit immediately by genetic counselling. If such a mother is demonstrated to be married to a sickle-cell carrier it is theoretically possible to offer her antenatal diagnosis and a therapeutic abortion if the fetus is found to have sickle-cell anaemia. At the present time, because of the small production of $\beta$ polypeptide chains in early pregnancy (nearly all the haemoglobin is fetal haemoglobin), the techniques required for intrauterine diagnosis are not refined enough to permit reliable clinical results before birth (Kan et al, 1972; Kazazian et al, 1972). However, neonatal diagnosis is possible using the cord blood samples. Such an early diagnosis gives many advantages in arranging medical care for the baby even though, because of the high level of fetal haemoglobin present at birth, the symptoms of sickle-cell anaemia do not manifest themselves in the first few months of life (Yawson et al, 1970).

\section{$\beta$ THALASSAEMIA}

$\beta$ thalassaemia is inherited in the same way as sicklecell anaemia and if a $\beta$ thalassaemia minor (carrier) mates with a $\beta$ thalassaemia minor (carrier) on average one quarter of their children will be normal; one half will be carriers of $\beta$ thalassaemia ( $\beta$ thalas- globins. Haemoglobin $\mathbf{C}$ is localized to West Africa and is also found in the New World Negro, many of whom originated from this area. The common haemoglobin D is called haemoglobin D Punjab, as that area of the Indian continent is the main reservoir. Finally, haemoglobin E occurs in a widespread area of the Far East, being found in the indigenous population rather than in the newly arrived Chinese. It is thus apparent that some indication of the abnormal haemoglobin likely to be present in a patient will be obtained from a knowledge of the ethnic origin, although such information is less valuable in areas of racial admixture such as Jamaica. Haemoblobins C, D and E all have aminoacid substitutions in the $\beta$ polypeptide chain and therefore the gene involved is the same as that in sickle-cell anaemia and $\beta$ thalassaemia, the $\beta$ polypeptide chain gene. The carriers of haemoglobins $\mathrm{C}, \mathrm{D}$ and $\mathrm{E}$ are quite symptomless and have normal haemoglobin levels. The homozygote states, haemoglobin $\mathrm{C}$ disease, $\mathrm{D}$ disease and $\mathrm{E}$ disease are all chronic haemolytic anaemias of variable severity, usually with splenomegaly. Like any chronic haemolytic anaemia, eg, heriditary spherocytosis, the haemoglobin may fall as a result of marrow depression or an increased rate of haemolysis, situations that may follow an infection. Again, the increased marrow activity required to maintain a reasonable haemoglobin level demands extra folic acid and folic acid deficiency may easily occur in pregnancy (figure 2 ). The inheritance would follow the pattern described for sickle-cell anaemia.
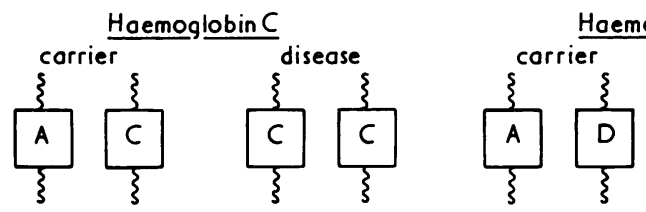

Fig. 2

saemia minor); and one quarter will die as children because they will have $\beta$ thalassaemia major.

Adequate genetic counselling for this condition must again depend upon accurate detection of carriers. The problems involved in reliably detecting $\beta$ thalassaemia minor, especially in areas where iron deficiency is also endemic, are much greater than in detecting the sickle-cell carrier.

In-utero diagnosis of $\beta$ thalassaemia major followed by therapeutic abortion is not yet a practical procedure (Nathan and Alter, 1975).

\section{Haemoglobins C, D and E}

There are three other common abnormal haemo-

\section{Sickle-cell Haemoglobin C Disease}

It is possible to have people carrying two abnormal but different $\beta$ polypeptide chain genes (doubly abnormal heterozygotes) and of the large number of theoretical possibilities only two need concern us here.

Sickle-cell haemoglobin $\mathrm{C}$ disease is the result of inheriting one sickle-cell gene from one parent and one haemoglobin $\mathrm{C}$ gene from the other. Because there is no normal $B$ polypeptide chain gene, there are no normal $\beta$ polypeptide chains produced and therefore no normal adult haemoglobin (haemoglobin A). The genetic situation may be represented as follows: 
Sickle-cell hoemoglobin C disease<smiles>CC1(C)CCC(C)(C)C1</smiles>

This situation commonly comes about when a sicklecell carrier mates with a haemoglobin $\mathrm{C}$ carrier, one in four children carrying both the sickle-cell and the haemoglobin $\mathrm{C}$ gene (figure 3 ). the disease will usually behave in a relatively mild manner, closer to that of the benign sickle-cell carrier than to that of the severe sickle-cell anaemia (in the sickle-cell carrier, normal adult haemoglobin is always the major part, which distinguishes this condition from sickle-cell $\mathrm{B}^{+}$thalassaemia where normal adult haemoglobin is always the minor part).

\section{Sickle-cell Haemoglobin}

The main reservoir of sickle-cell haemoglobin is $\left.\begin{array}{l}\text { Sickle-cell and } \\ \text { haemoglobin C }\end{array}\right\}$ Carriers

Reduction division

Random fertilization

Children

Fig. 3

\section{Sickle-cell $\beta$ Thalassaemia}

The second doubly abnormal heterozygote which warrants special mention is sickle-cell $\beta$ thalassaemia. Here one gene is the sickle cell $\beta$ polypeptide chain gene and the other is a $\beta$ thalassaemia gene.

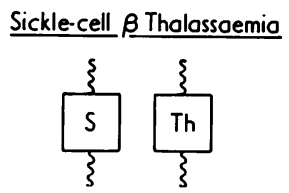

There are two types of $\beta$ thalassaemia gene: the $\mathbf{B}^{0}$ type produces no $\beta$ polypeptide chains and the $\mathrm{B}^{+}$ type produces a few, although the normal production rate has been considerably impaired. It thus follows that in the sickle-cell $\beta$ thalassaemia with the $\mathbf{B}^{0}$ type of thalassaemia gene there will be no normal $\beta$ polypeptide chains produced, the $\mathrm{B}^{0}$ thalassaemia gene being totally inactive, and the patient will possess only sickle-cell haemoglobin with a variable percentage of fetal haemoglobin. Such a patient will behave similarly to a case of sickle-cell anaemia. The sickle-cell $\beta$ thalassaemia with the $\mathrm{B}^{+}$type of thalassaemia gene may produce enough $\beta$ polypeptide chains, the $\mathrm{B}^{+}$thalassaemia gene having some activity, to end with about 70 per cent sickle-cell haemoglobin and 30 per cent of haemoglobin $\mathbf{A}$. Such a patient will be protected by the relatively large amount of normal haemoglobin present and central Africa (the carrier rate is commonly 20 per cent) where it is limited to the north by the Sahara desert and Ethiopian highlands and to the south by the rivers Zambesi in the east and Kunene in the west. It is found to a much lesser extent in the Middle East, India and the Mediterranean (particularly parts of Greece). In the New World, a sickle-cell haemoglobin is found in the American and West Indian Negro, who has a carrier rate of about 8 per cent.

This widespread distribution of sickle-cell haemoglobin would make it obligatory to screen all patients (even the native English) if no carriers are to be missed. In clinical practice it is usual to concentrate one's efforts upon the patient of Negro origin, as a screening programme involving all ethnic groups is likely to exhaust the laboratory facilities.

Sickle-cell haemoglobin is the most important of the hundred or so abnormal haemoglobins identified because, when oxygen is removed from the red cell, sickle-cell haemoglobin crystallizes out of solution and distorts the red cell into a sickle shape. Whenever this occurs, vessels may be blocked and the tissues fed by the vessels undergo infarction. This phenomenon of insolubility in the reduced form is not possessed by the other abnormal haemoglobins C, D and E.

There are a number of genetically determined conditions which have in common the presence within the red cell of a variable quantity of sickle-cell haemoglobin $(\mathrm{Hb} \mathrm{S})$. These conditions vary in 
severity from, at one end of the clinical spectrum, the almost completely benign sickle-cell carrier to-at the other end-the patient with the potentially lethal sickle-cell anaemia.

The term 'sickle-cell disease' is confined to those conditions where the presence of sickle-cell haemoglobin is commonly associated with symptoms, eg, sickle-cell anaemia, sickle-cell haemoglobin C disease and sickle-cell $\beta$ thalassaemia. It is customary not to consider the sickle-cell carrier as having sickle-cell disease, although even these fit carriers are liable on rare occasions to haematuria and, also, to infarctive crises if oxygen tension is very greatly reduced.

Sickle-cell syndromes

\begin{tabular}{ll}
\hline Sickle-Cell Carrier & Sickle-Cell Disease \\
\hline & 1 Sickle-cell anaemia \\
& 2 Sickle-cell haemoglobin C disease \\
& S Sickle-cell $\beta$ thalassaemia \\
\hline
\end{tabular}

In the United States literature 'sickle-cell disease' is often synonymous with sickle-cell anaemia.

\section{Sickle-cell Disease}

\section{CLINICAL COURSE}

A patient with sickle-cell disease usually maintains a haematological and clinical condition which, for that individual, can be recognized as the 'steady state'. It is important to collect the necessary data to establish a 'normal' haemoglobin level and other clinical parameters for each patient. This can be best achieved by attendance at outpatient clinics, and specialized 'sickle clinics' are being established which will provide this information and at the same time offer continuity of treatment. A deterioration (crisis) in this 'steady state' may have an alarmingly sudden onset and, on occasion, a fatal outcome.

\section{INFARCTIVE CRISIS}

The commonest form of crisis in patients with sicklecell disease is the infarctive crisis. This is caused by tangled sickled red cells obstructing blood vessels, which leads to tissue anoxia and ultimately to tissue death. Infarctive crises in bones, chest and abdomen are particularly common. Infarctions in the spleen are so common in sickle-cell anaemia that the spleen becomes impalpable due to scarring (autosplenectomy): in contrast, a palpable spleen is common in sickle-cell haemoglobin $\mathrm{C}$ disease and sickle-cell $\beta$ thalassaemia. Other sites for infarction are legion, and the patient may present with diagnoses as divergent as rheumatism, meningitis and acute appendicitis.

Infarctions of the bone marrow may result in sub- sequent detachment of dead tissue into the circulation and the resulting pulmonary emboli may be the cause of sudden death (Shelly and Curtis, 1958).

The pattern of infarction in pregnancy is much the same as in the non-pregnant women except that the former has an increased incidence of pelvic 'thromboses' (presumably exacerbated or even caused by intravascular sickling) which may again cause pulmonary emboli (Adams et al, 1953).

The increased incidence of eclampsia experienced by pregnant women with sickle-cell disease may again be caused by thromboembolic phenomena triggered off by intravascular sickling (Dale, 1949).

Patients who died of 'pseudo-toxaemia' (distinguished, by a normal diastolic blood pressure, from preeclampsia) were found to have marrow infarction and pulmonary emboli (Fullerton et al, 1965; Hendrickse et al, 1972).

Infarctive crisis in the pregnant woman requires particularly careful evaluation, especially when presenting as abdominal pain. A too complacent labelling of a patient as 'sickle crisis' may hide treatable obstetric hazards such as ectopic pregnancy or abruptio placentae (Pritchard et al, 1973).

A number of factors capable of precipitating an infarctive crisis are known and they are best avoided, if possible. They include infections (especially pulmonary infections) malaria, dehydration and vascular stasis, acidosis, cold and anoxia.

Information on placental pathology is very limited. Gross examination suggests normality (Hendrickse and Watson-Williams, 1966; Anderson, 1971) but microscopy may demonstrate sickling in the maternal sinuses (Anderson and Bushy, 1949; Adams et al, 1953; Song, 1971). The histological demonstration of intravascular sickling does not necessarily imply a physiological significance, as the changes may occur after separation of the placenta.

\section{APLASTIC CRISIS}

The aplastic crisis, caused by marrow depression, is associated with infections, especially of viral type. Because of the short red cell life span even in the 'steady state', a temporary depression of marrow activity can, in sickle-cell anaemia, cause a catastrophic fall in haemoglobin level and transfusion is then needed to maintain life. Marrow output failure may also result from a deficiency of folic acid, especially during pregnancy. The very high maternal mortality reported some years ago in Africa was greatly reduced by folic acid supplements given during pregnancy to patients with sickle-cell disease (Fullerton and Watson-Williams, 1962).

SEQUESTRATION CRISIS

This crisis particularly, but by no means exclusively, 
affects infants and young children. There is sudden massive pooling of red cells, especially in the spleen and immediate transfusion is needed to maintain life.

\section{HAEMOLYTIC CRISIS}

The red cell life span, which is normal in the sicklecell trait carrier, is shortened in all the varieties of sickle-cell disease, being about 17 days in sickle-cell anaemia. Any given figure will vary from patient to patient, and in any particular patient the red cell life span may, perhaps as a result of infection, be suddenly reduced (the haemolytic crisis) below the "normal' for that particular person.

\section{Maternal Risk}

All the above types of crisis can occur in both the pregnant and non-pregnant patient. The increased mortality around the period of delivery suggests an increased frequency and severity of crisis at that time.

It has already been stated that folic acid therapy will considerably reduce the maternal mortality. Iron deficiency is unusual in a chronic haemolytic anaemia, iron overload being a more usual problem. It must be remembered that on occasion iron deficiency can occur in patients with haemoglobinopathies and that this complication may require correction (Anderson, 1972).

Assuming that folic acid supplements are given, it is difficult to be dogmatic about the maternal risk to be expected. One of the major stumbling blocks to providing information of value to the obstetrician is the very variable severity of sickle-cell anaemia from one patient to another. Indeed, any child who survives until adolescence and, subsequently, becomes pregnant may in any case be at the milder end of the clinical spectrum of this disease process (Apthorp et $a l, 1963)$. In some cases, attenuating factors such as an unusually high level of fetal haemoglobin in the red cells (Charache and Conley, 1964) and the coexistence of $\alpha$ thalassaemia, are known to lessen the severity of sickle-cell anaemia (van Enk et al, 1972). In other cases the presence of another abnormal haemoglobin, eg, haemoglobin Memphis, within the red cell reduces the severity of the sickling process (Cooper et al, 1973). In many other cases where no such factors are demonstrable and where environmental influences appear reasonably to be equal, it is inexplicable why some cases of sickle-cell anaemia should run a severe course and others a mild.

Fort et al (1971) discuss this problem and point out that overall maternal mortality figures would include good-risk multiparous women with relatively benign sickle-cell anaemia having their fifth or sixth child. The inclusion of such cases would skew the results to make them too optimistic for a girl presenting in her first or second pregnancy with sickle-cell anaemia of average clinical severity. These authors suggest, after examining the records of 27 low-parity patients with 57 pregnancies, that it would be reasonable to assume a maternal mortality for sickle-cell anaemia and sickle-cell haemoglobin $\mathrm{C}$ disease in the region of 10 per cent. These figures may well be on the pessimistic side, and Pritchard et al (1973), for example, report no maternal deaths in their series of 50 pregnancies in 34 women with sickle-cell anaemia. They did, however, comment that maternal morbidity was frequent, at times intense and usually prolonged.

Good obstetric management is likely to play a part in reducing maternal mortality. Exhausting and diffcult labours are undesirable, but, as operative procedures are not without risk, caesarian sections should not be routinely undertaken (Morrison $e t$ al, 1972). In considering transfusion it is important to realize that sickle-cell haemoglobin releases oxygen more effectively than normal haemoglobin (Bellingham and Huehns, 1968) and one should not be overalarmed by low haemoglobin levels. Indeed, sudden overtransfusion may precipitate crisis by increasing blood viscosity. The level of haemoglobin at which transfusion is required is best judged by the clinical condition of the patient (Charache, 1974) and the 'steady-state' haemoglobin level, if known. The established infarctive crisis is difficult to treat (Huntsman, 1974), and, faced with a deteriorating clinical situation, a large-scale exchange transfusion may have a place (Green et al, 1975). In a particularly troublesome pregnancy partial exchange transfusions may have a prophylactic role (Morrison et al, 1972).

Relevant to obstetric management is the fact that the maternal mortality in other ethnic groups with sickle-cell anaemia is likely to be different from the Negro pattern. Saudi Arabians have an unusually benign form of this disease and not surprisingly no maternal fatalities were reported from a series originating there where the usual clinical course of sickle-cell anaemia is commonly alleviated by an unusually high level of fetal haemoglobin (Perrine and John, 1974).

The preceding discussion has centred around sickle-cell anaemia. Sickle-cell haemoglobin C disease has a somewhat different clinical course in that the patients are often well and in many cases undiagnosed, their haemoglobin levels being sometimes within normal limits. However, this disease process can produce the most violent, often unexpected and sometimes fatal crisis which is prone to be especially upsetting to the relatives, medical attendants and the coroner. In contrast, a typical patient with sickle-cell anaemia tends to stumble from crisis to crisis and a fatal outcome lacks this unwelcome 
element of surprise. The obstetrician is ill advised to regard sickle-cell haemoglobin $\mathbf{C}$ disease as a 'mild' type of sickle-cell disease and in the series by Pritchard et al (1973) of 78 pregnancies (43 women) two of the mothers with sickle-cell haemoglobin $\mathrm{C}$ disease died.

The clinical course for sickle-cell $\beta$ thalassaemia depends on whether the $\beta$ thalassaemia gene is of the $\mathrm{B}^{0}$ or $\mathrm{B}^{+}$type, ie, whether there is no normal adult haemoglobin or whether there is about 30 per cent of normal adult haemoglobin. The former behave clinically like sickle-cell anaemia and the latter usually behave clinically more like the sickle-cell trait, which is considered below.

Diggs (1973) has emphasized that well documented studies of maternal mortality, morbidity and neonatal death are urgently needed to provide more meaningful information than that at present available to the obstetrician caring for a pregnant woman with sickle-cell disease.

FETAL AND NEONATAL MORTALITY IN MOTHERS WITH SICKLE-CELL DISEASE

The birth weight of babies of mothers with sickle-cell anaemia is below average (Anderson et al, 1960) and the fetal wastage is high. The cause of neonatal death appears to be somewhat obscure, the postmortem findings being those of intrapartum anoxia (Anderson, 1971). On occasion, maternal bone disease may lead to pelvic deformity and malpresentation (Akinla, 1973) and this complication could affect the delivery of mothers with sickle-cell disease(Hendrickse et al, 1972). Fort et al (1971) quote that, of 97 pregnancies, there were 64 live births of which 50 survived the neonatal period. Although these figures are more pessimistic than others (Anderson, 1971; Pritchard et al, 1973), all workers in this field emphasize the high fetal and neonatal mortality. It must, in addition, be remembered that if married to a sickle-cell carrier, half the children born will themselves have sickle-cell anaemia, the mother passing a sickle-cell gene to every offspring and the father to every other. With a 10 per cent sickle-cell carrier rate, there is an overall 5 per cent chance of having a baby with sickle-cell anaemia. In advising a woman with sickle-cell disease on abortion and/or sterilization, it must be remembered that a family may well throw additional stress upon a woman who already carries a heavy burden of disease. Contraceptive advice is complicated by possible adverse reactions to oral contraception (Greenwald, 1970) but these risks are probably smaller than the unwanted pregnancy (Charache, 1974).

The fetal and neonatal mortality with mothers who have sickle cell haemoglobin $\mathrm{C}$ disease appears to be either roughly the same (Fort et al, 1971) or less
(Pritchard et al, 1973) than those expected from mothers with sickle-cell anaemia. One would envisage that the fetal wastage resulting from pregnancy of mothers with sickle-cell $\beta$ thalassaemia would be dependent upon the clinical severity of the mother's disease.

\section{Sickle-cell Trait Carrier and Pregnancy}

Low birth weights (Brown et al, 1972) and increased perinatal mortality (Platt, 1971) have been reported in the babies of sickle-cell carrier mothers. The majority of opinion, however, considers that the sickle-cell trait carrier has no higher maternal risk of neonatal mortality than one would expect from a control group of women (Pearson and Vaughan, 1969; De Lamerens et al, 1972; Pritchard et al, 1973).

However, as well as an increased liability to haematuria, there also appears to be a higher incidence of bacteriuria in pregnancy and the sickle-cell trait mother could represent a high-risk group for urinary tract infection (Whalley et al, 1964). Certainly, pregnant women with sickle-cell anaemia have been found to have a predisposition to urinary infections in pregnancy (Beacham and Beacham, 1951).

On severe deoxygenation, the red cells of patients with sickle-cell trait will eventually sickle and the oxygen tension at which this occurs can be easily ascertained in vitro. In vivo, sickling does not occur in areas where the arterial or venous $\mathrm{pO}_{2}$ is easily measurable but it is more likely to take place in the bone marrow and splenic sinuses where vascular stasis is a normal feature of the circulation. This situation greatly reduces the value of attempts to correlate the arterial or venous $\mathrm{pO}_{2}$ measurements with infarctive risk. However, even in the absence of scientific data, commonsense suggests that anaesthetic procedures that significantly reduce measurable $\mathrm{pO}_{2}$ levels must be, to a greater or lesser extent, hazardous to the sickle-cell trait carrier.

The percentage of sickle-cell haemoglobin in the sickle-cell carrier varies from person to person and ranges from about 20 per cent to 45 per cent. It would be expected that the red cells of those with the higher percentage of sickle-cell haemoglobin will sickle at higher $\mathrm{pO}_{2}$ levels and this can be demonstrated in vitro. It would be reasonable to assume that such patients may be at especial risk during an anaesthetic accident (Howells et al, 1972). Unfortunately, data on the morbidity, if any, of the sicklecell trait carrier are not readily available and the lack of animal models eliminates experimentation in vivo. It may be trite but it is also true to state that an anaesthetic that is inadequate for the sickle-cell trait 
carrier is also inadequate for the middle-aged, somewhat overweight male Caucasian!

Routine testing of pregnant women for sickle-cell haemoglobin will produce a great majority of sicklecell trait carriers and this information is currently carefully recorded and then ignored. In the future, some sickle-cell trait carriers may wish for genetic counselling and, when practicable, those married to sickle-cell carriers may ask for antenatal diagnosis. Patients with sickle-cell anaemia are likely to be already known and it would appear that the main purpose of antenatal testing for sickle-cell haemoglobin is to detect sickle-cell haemoglobin C disease: the potentially unpleasant nature of this variety of sicklecell disease has already been emphasized.

\section{Beta Thalassaemia}

Beta thalassaemia presents as a hypochromic anaemia, the red cells being pale because of their lack of haemoglobin. In this case, the lack of haemoglobin is caused by the lack of globin ( $\beta$ polypeptide chain production being impaired) and not a lack of iron.

Beta thalassaemia is a relatively common disorder, being carried in racial groups spread across the Mediterranean, Middle and Far East into China. The original name for $\beta$ thalassaemia major, Mediterranean anaemia, because it was recognized by Cooley in Italian immigrants to the United States, is clearly far too limiting and the obstetrician is just as likely to meet this disorder in an Indian woman as in a Cypriot. It is less usual but by no means rare to find $\beta$ thalassaemia in a Negro, an ethnic group that is the main reservoir of sickle-cell haemoglobin and haemoglobin $\mathrm{C}$.

BETA THALASSAEMIA MAJOR

Because of the continuing production of fetal haemoglobin during the first few months of life, the newborn child with $\beta$ thalassaemia major is at first protected from the severe anaemia resulting from the failure of $\beta$ polypeptide chain production. It is only when the fetal haemoglobin production falls away and adult haemoglobin fails to be produced, that the full effects of this disease become clinically apparent. The severe anaemia that develops is associated with massive hepato- and splenomegaly. The swelling of the marrow cavities results in some distortion of the normal bone structure, the prominent zygomas, for example, resulting in a characteristic 'mongoloid' facies. Beta thalassaemia major seldom presents diagnostic problems, because the parents of the child are in any case usually acquainted with the disease. A child with $\beta$ thalassaemia major will be expected to die in childhood or adolescence and the presence of this extremely unpleasant disease is incompatible with pregnancy.

The obstetrician is, however, likely to be involved in discussions concerning genetic counselling and antenatal diagnosis, which have already been considered when the inheritance of $\beta$ thalassaemia was discussed.

\section{BETA THALASSAEMIA MINOR AND \\ PREGNANCY}

The normal haemoglobin in late pregnancy is hard enough to define and the 'normal' haemoglobin for a pregnant woman with $\beta$ thalassaemia minor is virtually impossible to lay down. One has to remember that these women even in the most unsophisticated conditions are able to reproduce effectively, otherwise this particular disorder would be too disadvantageous to have increased to its present massive proportions.

Because of the large-scale haematological screening of antenatal patients, the obstetrician may well be the first medical attendant to be in a position to diagnose $\beta$ thalassaemia minor. All too often, the patient, because of a hypochromic anaemia, is assumed to be iron deficient and, when the response to therapy is poor, the label is changed to something such as 'iron-resistant anaemia'. The major danger is that long-term iron medication may be continued after delivery, because the patient may then be at risk of becoming iron overloaded.

It is, therefore, clearly important for the obstetrician to recognize the carrier of $\beta$ thalassaemia and then to prevent additional haematological stress by ensuring folic acid supplements. Under these circumstances one should hope to attain a haemoglobin which should be in the range of $10 \mathrm{~g} / \mathrm{d} 1$ (or above) and levels much below this would suggest additional complications.

Beta thalassaemia minor can be suspected because the mean corpuscular haemoglobin (MCH) obtained by an electronic cell counter is lower than that of an anaemic patient with a similar haemoglobin level suffering from iron deficiency. This is because the patient with $\beta$ thalassaemia minor has a greater number of red cells and the limited amount of haemoglobin available has to be shared out amongst a larger population. As a result, each red cell receives less haemoglobin and this is manifested by an unusually low mean corpuscular haemoglobin.

Because, in $\beta$ thalassaemia, only $\beta$ polypeptide chain production is impaired, it would be reasonable to expect a normal or even increased amount of fetal haemoglobin $\left(\alpha_{2} \gamma_{2}\right)$ and haemoglobin $A_{2}\left(\alpha_{2} \delta_{2}\right)$ to be present, because these two haemoglobins contain no $\beta$ polypeptide chains. Nearly all cases of $\beta$ thalassaemia minor have a raised level of haemoglobin $A_{2}$ 
(recognized by electrophoresis or column chromatography) and about half have a raised level of fetal haemoglobin (recognized by an alkali denaturation test or a 'Kleihauer' blood film stain, such as is used to demonstrate transplacental haemorrhage).

Although $\beta$ thalassaemia minor is classically associated with iron overload, it is becoming increasingly realized that women with this condition (even in the absence of detectable haemorrhage) are by no means immune from iron-deficiency anaemia (Fleming and Lynch, 1969). It is, however, important that iron deficiency should be proven by a serum iron estimation before iron therapy is commenced. In cases of doubt, the marrow fragments can be stained to give an estimate of the body iron stores.

Problems arise when attempting to diagnose $\beta$ thalassaemia minor in the presence of iron deficiency. Not only is the reading of the electronic cell counter complicated by a coexistent iron deficiency but also the haemoglobin $A_{2}$ level may fall to normal in the presence of this complication (Wasi et al, 1968). In these circumstances, it may be necessary to correct the iron deficiency before recognizing the presence of $\beta$ thalassaemia minor.

\section{ALPHA THALASSAEMIA}

Alpha thalassaemia implies an impaired production (probably through deletion of structural genes) of $\alpha$ poylpeptide chains. The geographical distribution is not clearly delineated but it may well be as widespread as is $\beta$ thalassaemia. Because haemoglobins A $\left(\alpha_{2} \beta_{2}\right)$, fetal haemoglobin $\left(\alpha_{2} \gamma_{2}\right)$ and haemoglobin $\mathrm{A}_{2}\left(\alpha_{2} \delta_{2}\right)$ all contain $\alpha$ polypeptide chains, the production of all these three haemoglobins is impaired. As a result, and depending on the age of the patient and the severity of the disease, tetramers of $\gamma$ chains ( $\gamma_{4}$ or haemoglobin Barts) and $\beta$ chains $\left(\beta_{4}\right.$ or haemoglobin $\mathbf{H}$ ) make their appearance.

The inheritance of $\alpha$ thalassaemia is not clear (Weatherall and Clegg, 1975) probably because the $\alpha$ polypeptide chain genes are duplicated giving a total of four genes responsible for $\alpha$ polypeptide chain production.

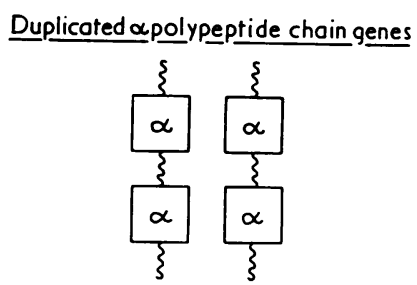

Whilst it may be oversimplified, it is useful to consider the clinical manifestations of $\alpha$ thalassaemia in three categories of severity: (1) $\alpha$ thalassaemia major (four $\alpha$ polypeptide chain genes deleted); (2) haemoglobin $\mathbf{H}$ disease (three $\alpha$ polypeptide chain genes deleted); and (3) $\alpha$ thalassaemia carrier states (one or two $\alpha$ polypeptide chain genes deleted).

ALPHA THALASSAEMIA MAJOR

(HB BARTS HYDROPS SYNDROME)

Alpha thalassaemia major has been described, especially amongst the Chinese, and is incompatible with delivery at term. In Malaysia, hydrops fetalis is more often due to $\alpha$ thalassaemia than to maternal/ fetal blood group incompatibility. Examination of the haemoglobin of the hydropic infant by electrophoresis will demonstrate no haemoglobins containing $\alpha$ polypeptide chains, eg, no $\mathrm{Hb} \mathrm{A,} \alpha_{2} \beta_{2}: \mathrm{Hb} \mathrm{F,} \alpha_{2} \gamma_{2}$ : $\mathrm{Hb} \mathrm{A}{ }_{2}, \alpha_{2} \delta_{2}$, the major haemoglobin being $\gamma_{4}$ or $\mathrm{Hb}$ Barts.

HAEMOGLOBIN H DISEASE AND PREGNANCY A less severe form of $\alpha$ thalassaemia, compatible with pregnancy, is haemoglobin $\mathbf{H}$ disease. Patients with this disease usually have a moderately severe anaemia, in the region of 8 to $10 \mathrm{~g} / \mathrm{dl}$, and some hepato and splenomegaly. Despite haematinics, this haemoglobin level would tend to fall in pregnancy. The presence of haemoglobin $\mathrm{H}$ can be demonstrated by special staining of the red cells for inclusions caused by the precipitation of the haemoglobin $\mathbf{H}$ within the red cell ( $\mathrm{H}$ body test) or alternatively by electrophoresis.

Such patients, who have a moderately severe haemolytic process, benefit from permanent folic acid therapy which is obligatory in pregnancy. The situation as regards iron therapy is identical to that discussed in $\beta$ thalassaemia minor, iron deficiency having to be proven before iron therapy is commenced.

Drugs must be selected with care because of a possible adverse reaction to oxidant drugs such as sulphonamides. These and other drugs, which can also adversely affect patients who are glucose-6phosphate dehydrogenase deficient, are best avoided if alternatives are available. Transfusion may be required to maintain a viable haemoglobin level during pregnancy.

CARRIERS OF ALPHA THALASSAEMIA

The carriers of $\alpha$ thalassaemia are difficult to detect. At birth they have a raised level of $\gamma_{4}$ (haemoglobin Barts) in their cord blood and later they may have occasional red blood cells which can be shown to contain haemoglobin $\mathbf{H}$ inclusion bodies. It is also possible that the electronic red cell counter may offer some guidance in diagnosis (as in $\beta$ thalassaemia minor) and in cases of doubt the rate of $\alpha$ polypeptide chain production may be measured using radio- 
active isotopes. It is strange that using the criterion of raised $\mathrm{Hb}$ Barts levels in the cord blood, $\alpha$ thalassaemia minor would appear to be common in Negroes. Despite this apparently high carrier rate, haemoglobin $\mathrm{H}$ disease and $\alpha$ thalassaemia major are virtually unknown in this ethnic group.

Because the molecular lesion of $\alpha$ thalassaemia is still not clearly understood rational genetic counselling would be difficult to carry out, even assuming that carriers could be accurately identified.

\section{Conclusion}

The pathological processes to be expected in pregnant patients with haemoglobinopathies must depend upon the establishment of an accurate diagnosis. Increasing emphasis is being laid upon the prevention of the possible complications, which have been outlined above, when the different disease processes are individually considered.

\section{References}

Adams, J. Q., Whitacre, F. E., and Diggs, L. W. (1953). Pregnancy and sickle cell disease. Obstet. and Gynec., 2, 335-352.

Akinla, O. (1973). Pregnancy and the skeletal complications of sickle cell disease. Postgrad. med. J., 49, 255-257.

Anderson, G. W., and Busby, T. (1949). Sickel cell anemia and pregnancy. Amer. J. Obstet. Gynec., 58, 75-89.

Anderson, M. F. (1971). The foetal risks in sickle cell anaemia. W. Indian med. J., 20, 288-295.

Anderson, M. F. (1972). The iron status of pregnant women with hemoglobinopathies. Amer. J. Obstet. Gynec., 113, 895-900.

Anderson, M. F., Went, L, N., MacIver, J. E., and Dixon, H. G. (1960). Sickle-cell disease in pregnancy. Lancet, 2, 516 521.

Apthorp, G. H., Measday, B., and Lehmann, H. (1963). Pregnancy in sickle-cell anaemia. Lancet, 1, 1344-1346.

Beacham, W. D., and Beacham, D. W. (1951). Sickle cell disease and pregnancy: a review of the literature with a analysis of the experience at the Charity Hospital, New Orleans. Obstet. Gynec. Surv., 6, 455-483.

Bellingham, A. J., and Huehns, E. R. (1968). Compensation in haemolytic anaemias caused by abnormal haemoglobins. Nature (Lond.), 218, 924-926.

Brown, S., Merkow, A., Wiener, M., and Khajezadeh, J. (1972). Low birth weight in babies born to mothers with sickle cell trait. J. Amer. med. Ass., 221, 1404-1405.

Charache, S. (1974). The treatment of sickle cell anemia. Arch. intern. Med., 133, 698-705.

Charache, S., and Conley, C. L. (1964). Rate of sickling of red cells during deoxygenation of blood from persons with various sickling disorders. Blood, 24, 25-48.

Cooper, M. R., Kraus, A. P., Felts, J. H., Ramseur, W. L., Myers, R., and Kraus, L. M. (1973). A third case of hemoglobin Memphis/sickle cell disease. Amer. J. Med., $55,535-541$.

Dale, M. (1949). Sickle-cell anemia complicated by pregnancy. J. Mich., med. Soc., 48, 1484-1486 and 1530.

De Lamerens, S. A., Lopez-Duran, A., and Morrison, J. C. (1972). The offspring of patients with hemoglobin S. gene: preliminary report. Sth. med. J., 65, 537-539.

Diggs, L. W. (1973). Chapter 14, In Sickle Cell Disease:
Diagnosis, Management, Education, and Research, edited by H. Abramson, J. F. Bertles, and D. L. Wethers. Mosby, Saint Louis.

van Enk, A., Lang, A., White, J. M., and Lehmann, H. (1972). Benign obstetric history in women with sickle-cell anaemia associated with a-thalassaemia. Brit. med.J., 4, 524-526

Fleming, A. F., and Lynch, W. (1969). Beta-thalassaemia minor during pregnancy, with particular reference to iron status. J. Obstet. Gynaec. Brit. Cwlth, 76, 451-457.

Fort, A. T., and Morrison, J. C. (1972). Motherhood with sickle cell and sickle-C disease is not worth the risk. Sth. med.J., 65, 531-533.

Fort, A. T., Morrison, J. C., Berreras, L., Diggs, L. W , and Fish, S. A. (1971). Counseling the patient with sickle cell disease about reproduction: pregnancy outcome does not justify the maternal risk! Amer.J. Obstet. Gynec., 111, 324327.

Fullerton, W. T., Hendrickse, J. P. De V., and WatsonWilliams, E. J. (1965). Haemoglobin SC disease in pregnancy. In Abnormal Haemoglobins in Africa, edited by J. H. P. Jonxis. Blackwell, Oxford.

Fullerton, W. T., and Watson-Williams, E. J. (1962). Haemoglobin SC disease and megaloblastic anaemia of pregnancy. J. Obstet. Gynaec. Brit. Cwlth, 69, 729-735.

Green, M., Hall, R. J. C., Huntsman, R. G., Lawson, A., Pearson, T. C., and Wheeler, P. C. G. (1975). Sickle cell crisis treated by exchange transfusion. J. Amer. med. Ass., 231, 948-950.

Greenwald, J. G. (1970). Stroke, sickle cell trait, and oral contraceptives. (Letter.). Ann. intern, Med., 72, 960.

Hendrickse, J. P. De V., Harrison, K. A., Watson-Williams, E. J., Luzzatto, L., and Ajabor, L. N. (1972). Pregnancy in homozygous sickle-cell anaemia. J. Obstet. Gynaec. Brit. Cwlth., 79, 396-409.

Hendrickse, J. P. De V., and Watson-Williams, E. J. (1966). The influence of hemoglobinopathies on reproduction. Amer.J. Obstet. Gynec., 94, 739-748.

Howells, T. H., Huntsman, R. G., Boys, J. E., and Mahmood, A. (1972). Anaesthesia and Sickle-Cell Haemoglobin. Brit. J. Anaesth., 44, 975-987.

Huntsman, R. G. (1974). Treatment of sickle-cell disease. Trans. roy. Soc. trop. Med. Hyg., 68, 80-84.

Kan, Y. W., Dozy, A. M., Alter, B. P., Frigoletto, F. D., and Nathan, D. G. (1972). Detection of the sickle gene in the human fetus. New Engl. J. Med., 287, 1-5.

Kazazian, H. H., Jr., Kaback, M. M., Woodhead, A. P., Leonard, C. O., and Nersesian, W. S. (1972). Further studies on the antenatal detection of the sickle cell anemia and other hemoglobinopathies. Advanc. exp. med. Biol., 28, 337-346.

Morrison, J. C., Fort, A. T., Wiser, W. L., and Fish, S. A. (1972) The modern management of pregnant sickle cell patients: a preliminary report. Sth. med.J., 65, 533-536.

Nathan, D., and Alter, B. P. (1975). Antenatal diagnosis of the haemoglobinopathies. Brit. J. Haemat., 31, Suppl., 143-154.

Pearson, H. A., and Vaughan, E. O. (1969). Lack of influence of sickle cell trait on fertility and successful pregnancy. Amer.J. Obstet. Gynec., 105, 203-205.

Pembrey, M. E., and Weatherall, D. J. (1971). Maternal synthesis of haemoglobin $F$ in pregnancy. (Abstr.) Brit. J. Haemat., 21, 355.

Perrine, R. P., and John, P. (1974). Pregnancy in sickle-cell anemia in a caucasian group. Amer. J. Obstet. Gynec., 118, 29-33.

Platt, H. S. (1971). Effect of maternal sickle-cell trait on perinatal mortality. Brit. med. J., 4, 334-336.

Pritchard, J. A., Scott, D. E., Whalley, P. J., Cunningham, F 
G., and Mason, R. H. (1973). The effects of maternal sickle-cell hemoglobinopathies and sickle-cell trait on reproductive performance. Amer. J. Obstet. Gynec., 117, 662-670.

Shelley, W. M., and Curtis, E. M. (1958). Bone marrow and fat embolism in sickle cell anemia and sickle cell-hemoglobin C disease. Bull. Johns Hopk. Hosp., 103, 8-26.

Song, J. (1971). Pathology of Sickle Cell Disease, p. 149. Thomas, Springfield, Illinois.

Wasi, P., Disthasongchan, P., and Na-Nakorn, S. (1968). The effect of iron deficiency on the levels of hemoglobins $\mathrm{A}_{2}$ and E. J. Lab. clin. Med., 71, 85-91.

Weatherall, D. J., and Clegg, J. B. (1975). Molecular basis of thalassaemia. Brit.J. Haemat., 31, 133-141.

Whalley, P. J., Martin, F. G., and Pritchard, J. A. (1964). Sickle cell trait and urinary tract infection during pregnancy. J. Amer. med. Ass., 189, 903-906.

Whitten, C. F. (1973). Sickle cell programming - an imperilled promise. New Engl. J. Med., 288, 318-319.

Yawson, G. I., Huntsman, R. G., and Metters, J. S. (1970). An assessment of techniques suitable for the diagnosis of sickle-cell disease and haemoglobin $\mathrm{C}$ disease in cord blood samples. J. clin. Path., 23, 533-537.

\section{General reading}

Lehmann, H., and Huntsman, R. G. (1974). Man's Haemoglobins including the Haemoglobinopathies and their Laboratory Investigation, 2nd ed. North-Holland, Amsterdam and Oxford.

Serjeant, G. R. (1974). The clinical features of sickle-cell disease North Holland Publishing Co Amsterdam, Oxford.

Song, J. (1971). Pathology of Sickle Cell Disease. Thomas, Springfield, Illinois.

Weatherall, D. J., and Clegg, J. B. (1972). The Tholassaemia Syndromes, 2nd ed. Blackwell, Oxford. 